\title{
MEREKONSTRUKSI MODEL KEPEMIMPINAN TRIPLE HELIX DALAM IMPLEMENTASI PEMBERDAYAAN MASYARAKAT DI ERA OTONOMI
}

\author{
Oleh : Alimas Jonsa \\ Email: alimasjonsa@gmail.com
}

\begin{abstract}
With Reconstructed of leadership model in triple helix implementation become the most important with the context of integrated nationality of Republic of Indonesia, post-reformation of leadership in Indonesia occurred drastically changing in leadership. It's become a policy of country in freedom autonomy local for managing, own regional, with various implementation model of society empowerment toward Indonesia independently and prosperity. That is inserted in Indonesia nationality at constitution of regional autonomy No. 32, 2004, that vision to be aspiration of $5^{\text {th }}$ namely toward justice for all Indonesia society. Thus, for obtain society vision justice and properity, needed the leadership model of Triple Helix in implementation of society empowerment, because that is become a new breakthrough to integrated elite group in conducting leadership in locally democratic era toward welfare. Leadership implementation of triple helix is a model of integrated of leadership thought in development of society empowerment independent and toward welfare, this integration is between government, academician, bussinessman to be one vision in context of development of society empowerment based on innovative, independent, toward welfare of local society in Indonesia
\end{abstract}

Keywords: Recontruction, leadership, empowerment, society, autonomy,

\begin{abstract}
Abstrak
Merekonstruksi model kepemimipinan dalam implementasi Triple Helix menjadi sangat penting dalam konteks negara kesatuan republik indonesa, pasca reformasi Kepemimpinan di indonesia terjadi perubahan yang drastis dalam hal kepemimpinan. Hal tersebut menjadi sebuah kebijakan negara dalam hal kebebasan lokal otonomi daerah untuk mengelola, daerah sendiri, dengan beragam model implementasi pemberdayaan masyarakat untuk menuju Indonesia yang mandiri dan sejahtera. Hal tersebut tertuang dalam Undang-Undang Otonomi Daerah No 32 Tahun 2004, Visi itu menjadi cita-caita bangsa indoesia yang tercantum dalam Undang-Undang Dasar Republik Indonesia Sila ke lima yakni menuju keadilan bagi seluruh rakyat indonesia. Sehingga untuk mendapatkan Visi masyarakat yang adil dan sejahtra, dibutuhkan model kepemimpinan Triple Helix dalam implementasi Pemberdayaan masyarakat, karena hal itu menjadi sebua trobosan baru menyatukan kaum elit lokal dalam hal pelaksanaan kepemimpinan di era demokrasi lokal menuju kesejahteraan. Implementasi kepemimpinan Triple Helix adalah, sebuah model penyatuan pemikiran kepemimpinan dalam hal ini pembangunan pemberdayaan masyarakat yang mandiri dan menuju sejahtera, penyatuan yang dimaksud adalah antara
\end{abstract}


pemerintah, Akademisi, dan pengusaha menjadi satu visi dalam konteks pembangunan pemberdayaan masyarakat yang berbasis inovasi, Mandiri, menuju kesejahteraan masyarakat lokal di indonesia.

Kata Kunci: rekonstruksi, Kepemimpinan, Pemberdayaan, Masyarakat, Otonomi,

\section{Pendahuluan}

Indonesia hari ini menjadi sebuah tantangan pembangunan dahsyat dalam hal negara kesatuan republik indonsia dengan konsep implementasi model kepemimpinan Triple Helix dalam era otonomi daerah, khususnya kepemimpinan lokal. Karena fenomenal dalam konteks kepemimpinan terjadi perubahan yang sangat drastis hal itu tumbuh ketika gerakan demokrasi menjadi geng perubahan dalam hal kepemimpinan kekuasaan pada tahun 1998. karena paska reformasi 21 mei 1998 sebuah zaman baru bagi indonesia terjadi tataran perubahan kekuasaan. A. Ubaedillah \& Abdul Rozak ( 2010 hal 1). Gelombang demi gelombang indonesia terus diuji dalam hal kedewasaan baik tingkat lokal, nasional maupun internasional. Otonomi daerah yang dilaksanakan dalam hal Undang-Undang Republik Indonesia tentang otonomi daerah hal itu tertuang dalam No. 32 Tahun 2004 menjadi sebuah penerobos baru (new generation) dalam hal pembangunan menuju indonesia yang mandiri dan sejahtera dalam hal otonomi daerah.

Topik ini peneliti mengambil tema sederhana dalam hal Pelaksanaan otonomi daerah menjadi sebuah ke khasan khusus bagi daerah otonom di indonesia. karena beberapa daerah di indonesia model kepemimpinan Triple Helix Sangat sulit diterapkan karena hal tersebut terjadi berbagai kepentingan elit sendiri dalam hal pusaran kepemimpinan. Faktor pertama penyebab Konflik antara lain adalah Faktor lokal, Pasangan Calon dan asal partai, pemilih dan dukungan politik, selanjutnya afiliasi politik pemilih,. yang kedua faktor nasional Transisi politik, Intervensi politik elit nasional, dampak kinerja terhadap pemerintah daerah yang tak searah Irtanto (2008, hal 35-63). hal ini peneliti menarik, kemudian mengupas kembali roh perjuangan bangsa indonesia menjadi ke arah jalan yang lurus. Model Kepemimpinan Triple Helix Dalam Implementasi Pemberdayaan Masyarakat di era otonomi berbasis gerakan perpaduan antara Akademisi (intelektual), Parah Bisnismen (pengusaha dan Government (pemerintahan) ini disebut sebagai ABG, dalam hal pembangunan daerah khususnya otonomi ke tiga pihak ini perlu bersatu dalam membangun bangsa ke arah mandiri dan aspek yang di banguan melalui kebijakan empowering system (sistem pemberdayaan) kepada masyarakat.

Beberapa daerah yang sudah mulai berhasil menerapakan Model Triple Helix dalam Implementasi kepemimpinan antara lain adalah sampai Tahun 2015 ini adalah, Kota Banda Aceh, Kota Bandung, Kota Yogyakarta, Surakarta, dan Kota Surabaya Bung Hatta Anti Corruption Award (2010 hal 4). Mereka berhasil merekonstruksi peradaban dalam hal memadukan antara kampus, pengusaha, dan government untuk menjadi pembangunan daerah bahkan di daerah tersebut diatas kepemimpinan mereka selalu mengutamakan kebijakan riset akademis dalam kepemimpinan daerah, sehingga apapun kebijakan yang mereka implementasikan dapat diukur 
dalam hasil yang maksimal. Berangkat dari judul diatas peneliti menarik judul tersebut untuk diangkat sebagai bahan renungan dalam kepemimpinan bangsa ini menuju masa depan indonesia yang lebih baik dan sejahtra dalam konteks otonomi daerah.

\section{Kajian Teoritik}

Deputi Bidang Kelembagaan Ilmu Pengetatahuan dan teknologi kementrian riset dan teknologi Freddy Permana Zen (Tempo, 30/6/2014), Mengatakan bahwa konsep kepemimpinan Triple Helix yang dikemukakan oleh Hatta Rajasa Pada Pedebatan Calon presiden bukan hal yang baru di indonesia, karena sebua sinergisitas atau istilah yang sering disebut dengan ABG Akademician, Bussines dan Government, hal ini diluar negri sudah menjadi sebuah sumber terlama dalam hal penerapan pembangunan.

Beberapa model kepemimipinan triple helix dengan peran masing dalam negara kesatuan dalam otonomi daerah, hal ini bisa dilaksanakan dengan pemerintah berperan sebagai pembuat regulasi dan melaksanakan sosialilsasi, adapun akademisi bertugas membuat penelitian dan mengeluarkan produk inovasi terbarunya sedangakan Pembisnis atau Industri berperan sebagai untuk menyokong dana, sayangnya hari ini indutri sokongan finansial yang sangat kecil dalam hal sumber dana.

Kota Banda Aceh yang salah satunya yang telah membangun konsep Triple Helix mencoba menerapkan penguatan swasta, pemerintah dan Universitas untuk membangun kemampuan penguasan pengetahuan kebencanaan dan knowledge Sharing kepada lain termasuk manca negara. Hal ini di kemukakan oleh wakil walikota banda Aceh Hj Illiza Sa'aduddin Djamal SE, yang saat ini telah menjadi walikota banda Aceh, hal tersebut di sampaikan dalam Training Course on Disaster Risk Management oleh Ir. T. Iwan Kusuma Banda Aceh Portal Kota Madani $(11 / 11 / 2013)$.

Beberapa gambar dalam model kepemimpinan "Triple Helix" yang di terapkan di daerah otonomi daerah seperti pemerinta kota banda aceh Propinsi Nanggroe Aceh Darussalam dalam hal implementasi gambar di bawah ini menunjukan Akedaemisi (universitas) yang penerobos utama gerakan, yang kedua pihak pengusaha (Business) dan yang ketiga government 


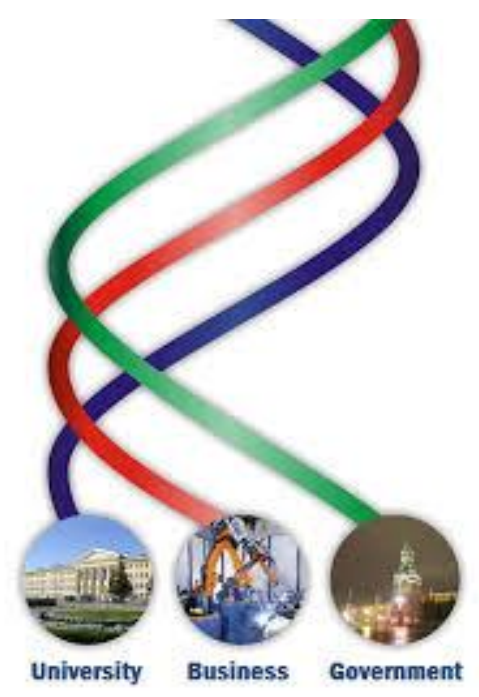

Gambar. 1

Model Triple Helix kota Banda Aceh tahapan sejajar posisi antara Akademisi, Business, da, Goverment

\section{Teori Sejarah Model Kepemimpinan Triple Helix Dalam Pemberdayaan Masyarakat}

Sejarah Istilah Triple Helix ini muncul dalam tulisan Fahmi Amhar, ketika mengamati Dr. Kusmayanto Kadiman, Mantan Rektor ITB yang perna menjadi Menristek yang mempopulerkan istilah tersebut " Triple Helix" untuk menggambarkan konstruksi ideal sinergi antara kalangan akademisi yang memproduksi riset dan Sumber Daya Manusia (SDM), dalam bidang sain dan teknologi, Kalangan Bisnis yang menggunakan hasil riset dan Sumber Daya Manusia tersebut, dan Kalangan Government atau pemerintahan yang membuat regulasi atau Undang-Undang agar semua berjalan dengan lancar, sinergisitas, konstruktif, dan bermartabat. Teori ini muncul dengan istilah "ABG" konsep tersebut selalu di sosialisasi kemanapun pergi dalam hal tamu, selalu mempopulerkan dengan istilah “ Triple Helix” Fahmi Amhar (1/10/2012).

Dalam Konsep model yang di populerkan oleh Mantan Rektor ITB tersebut selalu mensederhanakan kata-kata untuk menyuntik semangat "percuma menjadi peneliti senior, kalau risetnya tidak dipakai didunia bisnis atau tidak diperdulikan birokrasi", "Percuma menjadi Profesor kalau anak didiknya gagal didunia bisnis atau di birokrasi malah korupsi"," Percuma saja jadi bos perusahaan besar kalau tidak bisa memanfaatkan hasil riset dalam negri", "Percuma saja jadi birokrat, kalau tidak bisa memberikan iklim yang kondusif untuk tumbuhnya riset ataupun bisnis berbasis riset dalam negri".

Melihat sejarah bangsa lain ternyata di eropa "Triple Helix" mencapai titik final ketiganya melebur pada satu orang,Contohnya Tomas Alva Edison, Sang penemu lebih dari 1000 paten terkait pengguna listrik, ternyaa beliau adalah seorang pembisnis ulung (pendiri general electric) dan terkenal lobih-lobihnya dengan birokrasi di amerika saat itu. Hal yang sama juga terjadi yang lain, pada Henry Ford, Seichiro Honda, Steve Jobs, dan Bill Gates. Hal terkecuali pada Albert 
Einstein, karena beliau hanya memiliki "dual helix" yaitu sebagai saintis top peraih nobel fisika (akademisi) dan politisi (government) karena surat-suratnya saat ini mengemangkan bom atom.

Pada masa Islam memiliki peradaban emas di masa khalifa, pribadi triple helix sangat banyak antara lain bidang sains, dan bisnis tetapi juga kearah seni, siyasah (politik), ataupun petualangan contohnya Umar Khayam adalah mujtahid "Triple Helix" Selain matematikawan, dan sastrawan, disingkat ( 3 S) antara lain Syariah, Sains, dan Seni. Hal yang sama juga terjadi di Muhammad Al-Fatih adalah pemimpin pembebasan kontatinopel ( yang ramalkan Muhhammad sebagai sebaik panglima), tetapi beliau ternyata seorang tenokrat ulung yang memahami dengan detail berbagai sains teknologi peperangan beliau merancang konstruksi super-gun dan juga memberikan metode memindahkan kapal melawati pembuktian dan seorang eksekutif yang paham konsep syariah. Muhhammad Al-fatih juga mempunyai "(3 S)" Syariah- Siyasah (strategi)-sains.

Dengan melihat perkembangan sejarah diatas bahwa sangat jelas dalam konteks kajian peradaban sungguh sudah menjadi semangat reformasi sistem budaya dalam hal pusaran elit kekuasaan baik lokal maupun nasional dalam hal model kepemimipinan. Kepemimpinan model "Triple Helix" harus menjadi tugas besar elit nasional dan daerah dalam mempersiapkan pembangunan dalam hal kemajuan daerah dan bangsa untuk, menjadi sebuah tanggung jawab dalam hal implementasi sehingga menjadi sebuah pembangunan peradaban baru bagi bangsa bagi indonesia khususnya elit lokal dalam otonomi daerah.

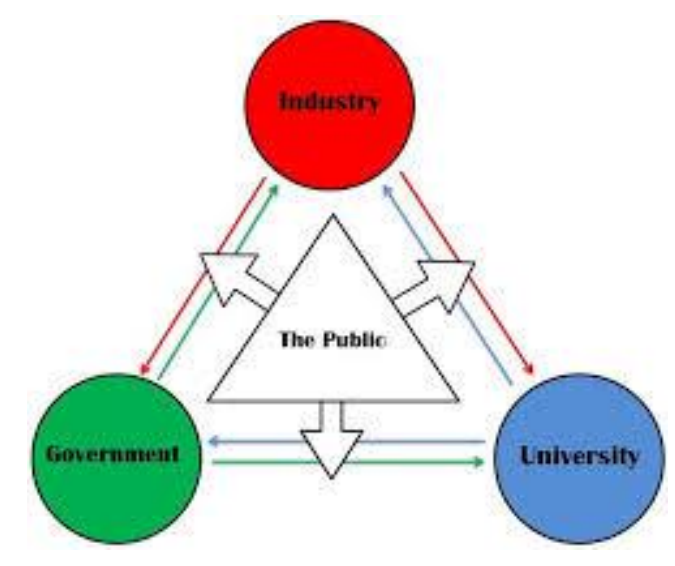

Gambar 2

Gambar kedua "Triple Helix" Government dan University menyokong Industri pasar diatas dan "publik ditengah".

Gambar keterangan diatas menunjukan bahwa Government (Pemerintah) dan University ( akademisi), menyongkong Industri (bisnismen) pengusaha sebagai rekor diatas untuk menumbuhkan semangat membangun budaya triple Helix, dalam membangun pradadaban bangsa ditengah pusaran menunjukan "The Public" Sebagai sasaran yang di bangun dalam hal empowering (pemberdayaan) untuk menuju welfare state (negara yang sejahtera). 
Dalam Bukunya Mohammad Amien Rais yang berjudul selamat Indonesia agenda mendesak bangsa (2008-hal 1) wajib kita cermati bahwa hal itu menunjukan betapa bangsa ini sudah sangat rapuh dalam hal toleransi terhadap sesama, belum lagi antara dalam tubuh pemerintahan saling tarik menarik kepentingan yang tidak pernah selesai, begitut juga dengan hal pengusaha selalu terjadi kesimpang siuran antara buruh dan pengusaha yang tidak perna selesai dalam membangun dialog antar kepentingan bersama. Selanjutnya pihak University (akademisi juga terjadi tarik ulur kepentingan bersama, sehingga tidak terjadi harmonisasi dalam hal membangun pradaban bangsa menuju yang lebih baik. Dalam hal ini peneliiti mengambil benang merah bahwa, yeng terjadi kemudian publik dalam tanda kutip masayarakat yang paling bawah menjadi sasaran ujung tombak untuk menjadi dalam kesimpngsiuran dengan alasan karena belum terbangun peradaban pemikiran dalam hal kepemimpinan triple helix.

\section{Metode Penelitian}

Metode yang digunakan dalam penelitian ini adalah metode penelitian kualitatif Noeng Muhadjir (1994 hal 94). dimana yang di cari adalah pemahaman atas suatu fenomena sosial, sehingga menjadi fokus utama adalah memperoleh pemahaman atau tindakan dan makna gejala sosial dalam sudut pandang penelitian. Dalam penelitian ini menggunakan pendekatan penelitian kepustakaan (liberary research) oleh karena itu sumber-sember data yang digunakan dalam penelitian ini berasal dari bahan tertulis baik berupa bahasa indonesia yang mempunyai relevansi dengan permasalahan yang ada penelitian ini maupun dengan sumber yang berhubungan dengan yang lainnya. Sementara tipe penelitian yang digunakan dalam penilitian ini adalah deskriptif dengan maksud memberikan gambaran mengenai gejala sosial tertentu yang ada dalam masyarakat dengan menggunakan pola berfikir induktif yaitu cara berfikir dari hal yang bersifat khusus ke umum, Lexi J. Moleong ( 2013 hal 3).

\section{Pembahasan}

Pada Penelitian ini mengangkat tema yang sederhana yaitu Merekonstruksi Model Kepemimpinan Triple Helix Dalam Implementasi Pemberdayaan Masayarakat Di era Otonomi, pada kesempatan ini peneliti mengangkat dengan sederhana dalam tataran model kepemimpinan triple helix dalam rana kekuasaan otonomi daerah. Beberapa kasus yang terjadi di indonesia kepemimipinan model triple helix ini masih sangat jauh dari yang di harapakan oleh negara itu sendiri. Karena konflik kepentingan menjadi lebih utama dalam hal pusaran kekuasaan hal ini bisa dilihat disetiap daerah di indonesia, mulai dari pemeilihan presiden, gubernur, maupun bupati dan walikota, beberapa kasus terjadi kekacauan konflik pilkada hal ini sangat merambat dalam hal kepimimpian sehingga otonomi dalam hal ini hanya menciptakan raja-raja lokal baru didaerah, karena hal ini king Maker punya berjalan sendiri-sendiri M. saleh Soeaidy (2005 hal 326). Memudarnya sifat karakter gotong royong, kesetiaan kawananan sosial, toleransi, saling menghargai ini kembali memudar dalam konteks negara kesatuan republik indonesia, padahal kalau melihat sejarah masa silam sungguh sangat luar biasa melihat liku-liku perjuangan bangsa ini untuk menjadi merebut kemerdekaan dari penjajahan. Hal tersebut bisa dilihat dalam sejarah 
pendirian bangsa indoensia, misalnya dengan mengusir belanda dari indonesia selama 3, setengah abad di jajah oleh belanda, belum lagi kalau melihat jepang tiga setengah tahun kemudian juga terjadi pengusiran dan mereka gulung tikar dari negeri ini.

Hari ini indonesia Kembali di Uji dengan berbagai macam gejolak, dalam hal kepemimpinan sehingga menjadi sebuah tugas besar bagi Pemerintah baik nasional maupun daerah hal ini mulai dari kemiskinan, pengangguran, Pembalakan liar ilegal loging, pembakaran hutan, SDM yang rendah, konflik sosial, korupsi sampai ke separatis ingin memisahkan dari negara kesatuan republik indonesia. begitu juga dengan parah pengusaha terjadi berbagai macam fenomena mulai dari gaji murah untuk parah buruh sampai ke pemutusan hubungan kerja, begitu juga dengan akademisi yang tidak selesai dalam hal merevolusi pendidikan di indonesia rendahnya angka Indeks manusia, belum lagi sifat tidak mampunya merevolusi pendidikan dalam hal dunia kerja hal ini akademisi baru berhasil hanya menciptakan para pencari kerja tapi bukan menghasilkan pencetak generasi menciptakan lapangan kerja.

Dengan berbagai macam problem Sosial diatas seharusnya parah pemangku kepentingan harus selalu membangun sinergisitas dalam merevolusi daerahnya dalam hal pemberdayaan masyarakat, Dalam Hal ini peneliti menawarkan sebuah konsep harmonis yaitu membangun kembali budaya gotong royong yang dalam hal ini untuk menyatukan persepsi dengan pola merekonstruksi kembali budaya kepemimpinan Triple Helix Dalam Implementasi Kekusasaan baik di nasional maupun di daerah sehingga hal tersebut bisa menjadi sebuah trobosan baru dalam membangun umat manusia yang menuju kesejaheraan dalam negara kesatuan republik indoensia.

Memang menyatukan kepemimpinan aktor tidak mudah akan tetapi hal ini harus sadar diri demi mesa depan bangsa dan anak cucu, konsep ini akan bisa berjalan kalau setiap porsi ini sesuai dengan ke ahlian masing-masing dalam penerapan membangun bangsa ini untuk kepentingan bersama bukan untuk kepentingan perbadi, dan saling percaya diri dalam hal setiap pemangku kekusaan sehingga tidak tarik ulur dalam hal kepentingan ego dan kelompok masing-masing porsi kekuasaan. Beberapa negara maju seperti amerika, cina, korea selatan, taiwan dan malaysia sudah menjadi budaya pembangunan baru untuk menjaga kepentingan nasional negara mereka, dan konsep triple helix sudah berjalan efektif dalam hal pusaran kekuasaan sehingga negara mereka percaya diri dalam hal pembangunan bangsa ke arah yang lebih sempurna. Beberapa contoh kasus negara yang sudah menjadi nyata negara taiwan ketika persentasi di aula Universitas Teuku Umar meulaboh aceh barat Tahun 2015. Ketika Persentas tentang negara Taiwan di awal pembukaan, selalu mempromosikan nama produks asal negara mereka salah satu contoh adalah pertanyaan apakah parah hadirin di Ruangan ini perna mendengar Nama Asus, Samsung, dan yang lainya ini salah satu hal bahwa akademisi mereka kemana pun pergi selalu memamerkan prokduk daerahnya sendiri. Sehingga kalau melihat fenomena tersebut sangat jelas parah akademisi mereka, sangat prihatin terhadap dunia usaha negara taiwan, dan otomatis ini kepentingan negara dalam budaya produknya menjadi penting untuk selalu di jaga dalam hal kepentingan nasional daerah.

Kepemimipinan Model Triple Helix ini bukan hal yang baru dalam implementasi kehidupan bernegara sehingga hal ini menjadi sebuah pengurangan ego dalam membangun bangsa. Pembangunan Model Konsep Triple Helix Ini menjadi sangat penting karena melihat situasi bangsa yang semakin hari semakin menurun dalam hal persaingan global . Dalam Penulisan 
ini peneliti mengingatkan kembali kepada para Pemimpin negri ini mulai dari Akedemisi, Bisnismen (pengusaha) dan Government (pemerintah) menyatukan kembali pemikiran sehingga porsi kekusaan masing Triple Helix ini bisa di laksnakan menjadi bermanfaat bagi kehidupan manusia.

Beberapa daerah yang sudah mulai berhasil menerapakan Model Triple Helix dalam Implementasi kepemimpinan antara lain adalah sampai Tahun 2015 ini adalah, Kota Banda Aceh, Kota Bandung, Kota Yogyakarta, Surakarta, dan Kota Surabaya Bung Hatta Anti Corruption Award (2010 hal 4). Mereka berhasil merekonstruksi peradaban dalam hal memadukan antara kampus, pengusaha, dan government untuk menjadi pembangunan daerah bahkan di daerah tersebut diatas kepemimpinan mereka selalu mengutamakan kebijakan riset akademis dalam kepemimpinan daerah, sehingga apapun kebijakan yang mereka implementasikan dapat diukur dalam hasil yang maksimal. Dalam catatan peneliti kedepan Kabupaten Aceh Barat juga sudah mulai memadukan konsep "Triple Helix" dan akan melakukan hal yang sama seperti daerah diatas dan telah tampak di depan mata, bahkan dalam sejarah republik indonesia tidak perna menegrikan dalam satu daerah tiga negeri kampus dalam satu tahun, baik dalam kelas propinsi maupun kabupaten kota, dan hal nobel tersebut pemerintah kabupaten aceh barat pada tahun 2014 dapat diraih telah menegrikan tiga kampus dalam setahun, dan dengan melihat fakta ini sungguh bahwa kepemimpinan Triple Helix menjadi penting dalam membangun pradaban bangsa untuk daerah lain di indoensia.

\section{Kesimpulan}

Kepemimipinan Model Triple Helix ini bukan hal yang baru dalam implementasi kehidupan bernegara sehingga hal ini menjadi sebuah pengurangan ego dalam kepemimpinan membangun bangsa. Pembangunan Model Konsep Triple Helix Ini menjadi sangat penting karena melihat situasi bangsa yang semakin hari semakin menurun dalam hal persaingan global maupun lokal . Dalam Penulisan ini peneliti mengingatkan kembali kepada para Pemimpin negri ini mulai dari Akedemisi, Bisnismen (pengusaha) dan Government (pemerintah) menyatukan kembali pemikiran sehingga porsi kekusaan masing Triple Helix ini bisa di laksnakan menjadi bermanfaat bagi kehidupan manusia negara republik indonesia. Sehingga Output dari Pembangunan "Triple Helix ini menjadi sebuah pembangunan baru dalam hal kepemimpinan di dunia menuju yang sempurna salam indonesia untuk perubahan.

\section{Saran}

Beberapa deerah yang mulai berhasil menerapakan Model Triple Helix dalam Implementasi kepemimpinan antara lain adalah sampai Tahun 2015 ini adalah, Kota Banda Aceh, Kota Bandung, Kota Yogyakarta, Surakarta, dan Kota Surabaya Bung Hatta Anti Corruption Award (2010 hal 4). Mereka berhasil merekonstruksi peradaban dalam hal memadukan antara kampus, pengusaha, dan government untuk menjadi pembangunan daerah bahkan di daerah tersebut diatas kepemimpinan mereka selalu mengutamakan kebijakan riset akademis dalam 
kepemimpinan daerah, sehingga apapun kebijakan yang mereka implementasikan dapat diukur dalam hasil yang maksimal.

Saran Peneliti adalah kedepan Kota yang menuju "Triple Helix" jangan hanya deerah tersebut di atas saja akan tatapi deerah yang lain juga harus mampu melakukan pendobrak perubahan di negri ini sehingga menjadi sebua agent of change menuju globalisasi patner dalam hal kepemimpinan. Dengan menerapkan konsep triple helix indonesia bisa maju dan tidak lagi di cap sebagai negara yang amburadul. Salam Perubahan

\section{Daftar Pustaka}

-, Undang-Undang Otonomi Daerah No 32 Tahun 2004, Pemata Press. Jakarta

-, A. Ubaedillah \& Abdul Rozak, 2010. Pendidikan Kewarganegaraan Civic Education Pancasila, Demokrasi, HAM, dan Masayarakat Madani. ICCE. Jakarta

-, Irtanto, 2008. Dinamika Politik Lokal Era Otonomi Daerah. Pustaka Pelajar. Yogyakarta.

-, Tempo, 30 Juni 2014, Diunduh dari pemilu.tempo.co/read/news/2014/06/30/26958912 kode kamis 5 november 2015.

-, Portal 11 November 2013, Diunduh dari http://bandaacehkotamadani.wordpress.com, Kamis 5 November 2015.

-, Portal 10 Januari 2012, Diunduh dari www.globalmuslim.web.id, kamis 5 November 2015.

-, Mohammad Amien Rais, 2008. Agenda- Mendesak Bangsa Selamatkan Indonesia. PPSK PRESS. Yogyakarta.

-, Noeng Muhadjir, 1994. Metodelogi Penelitian Kualitatif. Rakesarasin. Yogyakarta.

-, Prof. DR. Lexi J. Moleong, M.A., 2013. Metodologi Penelitian Kualitatif Edisi Revisi. Remaja Rosdakarya. Bandung.

-, Alfitra Salam \& Syamsudin Haris, 2005. Desentralisasi \& Otonomi Daerah Desentralisasi, Demokratisasi \& Akutanbilitas Pemerintah Daerah. AIPI, LIPI, Jakarta.

-, Best Practice Anugerah BHACA, 2010. Memupuk Optimisme Dari Daerah. Yayasan Tahija. Jakarta. 
